\title{
Progressive Multifocal Leukoencephalopathy
}

\author{
Reginald C. Adiele ${ }^{1,2,3^{*}}$ and Chiedukam A Adiele ${ }^{4}$ \\ ${ }^{1}$ Department of Anatomy and Cell Biology, College of Medicine, University of Saskatchewan, Saskatoon, SK, Canada \\ ${ }^{2}$ Cameco MS Neuroscience Research Center, University of Saskatchewan, Saskatoon, SK, Canada \\ ${ }^{3}$ Department of Biomedical Sciences, Western College of Veterinary Medicine, University of Saskatchewan, Saskatoon, SK, Canada \\ ${ }^{4}$ Department of Clinical Pharmacy, Faculty of Pharmaceutical Sciences, University of Nigeria, Nsukka, Nigeria
}

"Corresponding author: Reginald C. Adiele, DVM, PhD, Department of Anatomy and Cell Biology, Cameco MS Neuroscience Research Center, University of Saskatchewan, Saskatoon City Hospital, 701 Queen Street, Saskatoon, SK, S7K 0M7, Canada, Tel: 306 881-3811; Fax: 306 655- 8709; E-mail: radiele@upei.ca

Received date: Aug 06, 2014, Accepted date: Sep 23, 2014, Published date: Sep 26, 2014

Copyright: ( 2014 Adiele RC, et al. This is an open-access article distributed under the terms of the Creative Commons Attribution License, which permits unrestricted use, distribution, and reproduction in any medium, provided the original author and source are credited.

\begin{abstract}
Progressive multifocal leukoencephalopathy $(\mathrm{PML})$ is a rare, myelin-damaging disease of the central nervous system (CNS) in a setting of immunosuppression that is superimposed by concurrent autoimmune diseases such as multiple sclerosis and AIDS or simultaneous administration of immune modulatory monoclonal antibody drugs such as natalizumab. The causative agent is a Polyomavirus known as John Cunningham (JC) virus (JCV) that affects oligodendrocytes and astrocytes resulting in focal, extensive and progressive demyelination across the brain. The pathogenesis of JCV latent and active infection is yet to be fully understood despite significant medical research. To date, no therapeutic intervention has been very effective in addressing the health implications of PML. In this article, we review the current knowledge on the life cycle of JCV, pathogenesis of PML, highlight important tools in the diagnosis, potential targets for management and therapeutic intervention of PML.
\end{abstract}

Keywords Progressive multifocal leukoencephalopathy; JC virus; Oligodendrocyte; Astrocyte; Pathogenesis; Latency; Natalizumab

\section{Introduction}

Progressive multifocal leukoencephalopathy (PML) is a rare myelin-degrading disease of the central nervous system (CNS) caused by infection of oligodendrocytes and astrocytes by a Polyomavirus known as John Cunningham (JC) virus (JCV), whose name was taken after the first patient in which the virus was first isolated [1]. The virus belongs to the family of polyomaviridae [1-4]. Its genomic constituent is small, circular, and double-stranded DNA molecule of approximately 5100 base pairs that is divided into two protein coding regions (early and late) on opposite side of the non-coding control region (NCCR). The NCCR controls the enhancer and promoter regions of the coding element as well as the center of viral replication [5-7].

This opportunistic pathogen is wide-spread among human population and may or may not be accompanied with inflammatory changes. The primary target of PML is an immunosuppressed individual, inherently in association with autoimmune diseases such as multiple sclerosis and AIDS, inflammatory diseases including rheumatoid arthritis, systemic lupus erythematosus and sarcoidosis and or as a side effect of a disease modifying treatment such as monoclonal antibody therapy or cytotoxic drugs [8-11]. A common denominator in all the cases of PML is that the patient's immune system is compromised indicating lack of immunosurveillance.

\section{Pathophysiology of progressive multifocal leukoencephalopathy}

The viral agent implicated in this autoimmune disorder has been described over eight decades ago with subsequent identification of the viral particle in intranuclear inclusion bodies of myelin forming oligodendrocytes $[12,13]$ and its isolation from human brain suffering from PML [1]. The disease is associated with a long standing asymptomatic state of latency [1]. It affects many organ systems in the body including the tonsil, kidneys and CNS with a long period of latent inactive infection despite significant antibody seropositivity in the target population. Despite a high prevalence of up to $90 \%$ seropositivity, fulminant active infection is considerably very low $[14,15]$. This suggests that seropositivity does not portend active infection however, an immune compromised individual is at a very high risk of coming down with the infection. PML is been associated with numerous autoimmune and inflammatory diseases such as multiple sclerosis (MS) [9], acquired immune deficiency syndrome (AIDS) [16-21], lymphocytic leukemia [22], or during organ transplant co-administration of immunosuppressant drugs. Recent reports suggesting that immune modulation played critical role in the activation of JCV have attracted a lot of attention [3,9,11,23]. The hypothesis is reinforced by the resurgence of active PML in patients that are undergoing immunomodulatory therapeutic intervention $[23,24]$. Many of these reports of active PML have been linked to a reactivation of a supposedly "quiescent" JC virus by monotherapeutic or combination immunoregulatory therapy using monoclonal antibodies such as natalizumab, efalizumab, and rituximab [3].

\section{Pathogenesis of progressive multifocal leukoencephalopathy}

The life cycle of JCV is illustrated in Figure 1. The first step in tackling the scourge of PML is to have an indebt understanding of the mechanism of disease pathogenesis. PML infection is thought to occur early in the life of an individual and it is most likely transmitted through the natural external orifices of the gastrointestinal and respiratory tracts [25-27]. Subsequently, the virus invades local lymphoid tissue and infect the lymphocytes through which other parts of the body such as bone marrow and kidneys become infected and 
remain is these sites for a period of latency prior to setting up an active infection in an immune deficient subject $[28,29]$. It is highly possible that JC virus may have been carried to the brain by B lymphocytes carrier where they remain in a period of latency pending reactivation of the virus due to immunosuppression and lack of immune control. A period of latent infection occurs which is followed by active viremia and lodgement of the virus in various tissues of the body including the kidneys [30], tonsils, [28,31] and brain [32-34] as well as in white blood cells $[35,36]$.

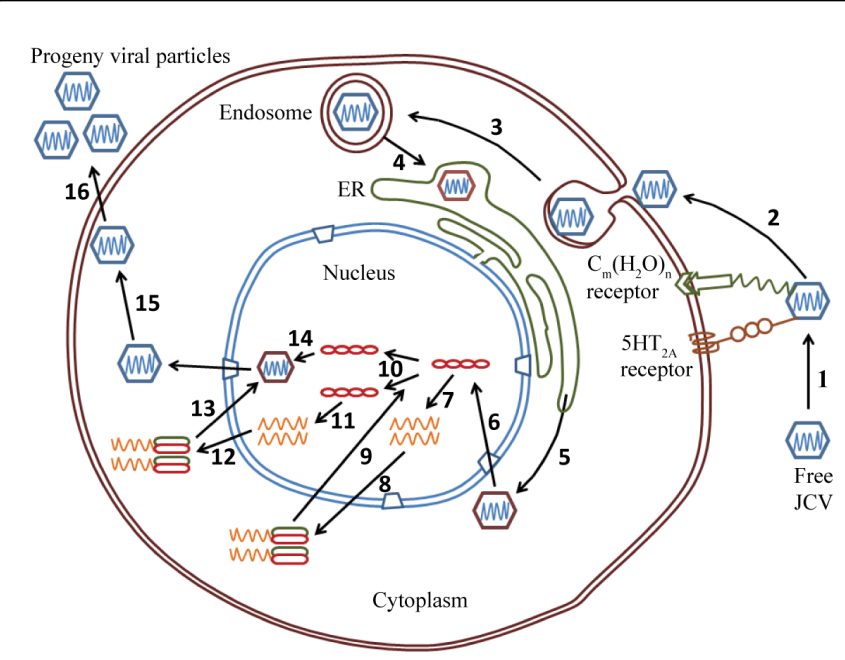

Figure 1: Life cycle and cellular events in JCV infection indicated by numbers accordingly. 1 : free JCV binding to carbohydrate $\left[\mathrm{C}_{\mathrm{m}}\left(\mathrm{H}_{2} \mathrm{O}\right)_{n}\right]$ receptor coupled serotonin $(5 \mathrm{HT} 2 \mathrm{~A})$ receptors on cell surface, 2: phagocytosis of viral particle, 3: transcytosis and formation of endosome, 4: internalization into endoplasmic reticulum (ER), 5: cytoplasmic translocation from ER, 6: nuclear internalization via nuclear pores for exsheathment and nuclear processing, 7: transcription of early viral coding region, 8: translation of early mRNAs, 9: nuclear relocalization, 10: replication of viral particle, 11: transcription late viral coding region, 12: translation of late viral transcript, 13: nuclear localization of capsids, 14: final nuclear packaging, 15: intracellular release of viral particles, 16: extracellular release of free JC viral progeny ready to infect other cells.

Among the neuroglia, oligodendrocytes and astrocytes are the main targets of JC virus whose infection results in severe demyelination and inflammation marked by infiltration with macrophages [32,37-40]. Following JCV binding to cellular surface sialic acid-linked carbohydrate receptor $[41,42]$ coupled to serotonin receptor, $5 \mathrm{HT}_{2 \mathrm{~A}} \mathrm{R}$ $[43,44]$, the viral particles become internalized by endocytosis (Figure 1). Endosome is formed, mediate by a vesicular capsid protein, clathrin, for onward translocation into the nucleus [45,46] via the endoplasmic reticulum (ER) [47]. In the nucleus, the viral particle undergoes DNA replication, transcription and encapsulation [38,39] and subsequently released as free active progeny virions with the potential to infect many more cells. Sequel to the release of the viral particle, the infected neuroglia undergoes necroses that is accompanied by the infection of adjacent glial cells in progression and terminally result in precipitation of PML.

\section{Active progressive multifocal leukoencaphalopathy}

The mechanism of activation of latent PML infection is unclear and requires more investigation to unravel the order of events that leads to activation of latent infection. It has been observed that HIV-1 transactivator protein Tat is a positive effector of transcription and replication process of PML. This observation offers some explanation on the concomitant increase in active PML infection in AIDS patients $[48,49]$. In a setting of immune deficiency and lack on immune surveillance, increased viral multiplication that subsequently results into increased viral load will promote dissemination of the viral particle and formation of lesions associated with PML. Further, depressed immune system is incapable of fighting infection and clearance of the viral particle because of lack of cells that are involved in immunosurveillance such the cytotoxic CD8 T cells whose role of fighting and eradicating infection is impaired [50]. Immune modulation by monoclonal antibody therapeutic agents prevents translocation of $\mathrm{T}$ lymphocyte through the $\mathrm{BBB}$. This eventually reduces $\mathrm{T}$ cell-linked immunosurveillance in the brain that result in the promotion of downstream activation of latent PML infection in the brain [51].

\section{Lesion location and clinical characteristics of progressive multifocal leukoencephalopathy}

Like most demyelinating diseases of the CNS that affect oligodendrocytes and to some extent astrocytes such as multiple sclerosis, PML exhibit multiple symptoms, affecting several organs and systems of the body that receive neural input from the brain and therefore the clinical picture is non-specific. The clinical manifestation and neurological impairment in PML are dependent on demyelination, location, size and distribution of PML plaques in the brain. Lesions could be focal, more generalized and observed throughout the brain including the cerebral and cerebellar hemispheres as well as the brain stem [52]. Demyelinated plaques are sometimes confluent, bilateral, and asymmetrical and may be localized in both the gray and subcortical white matter as seen in MRI [53]. Involvement of the cerebral subcortical and periventricular white matter may interfere with motor function implicating pyramidal and or extrapyramidal motor control centers, gait ataxia, altered mental status, speech disorders, sensory and visual impairment [54-56]. All regions of the cerebral hemisphere are potential targets of attack by this virus; however the frontal, parietal and occipital lobes are most frequently affected [57]. Accompanying seizure is suggestive of gray matter involvement $[56,58]$. The deep gray matter of the cerebrum and the brainstem are not spared by JC virus. Lesions are distributed in the basal nuclei, thalamus and pontine gray and white matter $[59,60]$. PML lesion localization in the cerebellum is inevitably expressed as cerebellar syndrome [61-63]. Sometimes, meningitis and meningoencephalitis have been associated with JCV infection suggesting that this viral particle play some role in promoting inflammatory changes in the brain $[64,65]$. When inflammation is involved especially during the degradation of myelin sheaths, inflammatory cells such as macrophages are recruited to clean-up byproducts of myelin breakdown [66].

\section{Diagnosis of progressive multifocal leukoencephalopathy}

A combination of clinical signs, laboratory tests, histopathological findings and diagnostic imaging techniques are employed to arrive at a definitive diagnosis of PML. Detection and identification of JC viral particle, protein and or DNA fragments in brain tissue samples and or 
cerebrospinal fluid polymerase chain reaction (CSF-PCR) for JC virus DNA could serve as a definitive diagnosis of active JCV infection $[1,66]$. Histopathologically, PML presents as focal or extensive and progressive demyelination and rarely accompanied by inflammation [67]. Histopathology is still the gold standard diagnostic technique to identify PML but it is flawed by its invasiveness and can only be carried out on biopsy or autopsy samples. Further, histological investigation only gives a snap shot in time event, which makes it difficult to provide crucial information on the onset, progression and evolution of disease pathogenesis over time. However, clinical and biomedical imaging techniques such as MRI are essential and supportive howevere findings have to be correlated with histopathological observations $[59,60]$.

\section{Therapeutic intervention in progressive multifocal leukoencephalopathy}

To date, there is relatively no effective treatment for PML. Many therapeutic agents have been used to mitigate the health effects of PML with variable or no significant beneficial effects and sometimes the adverse effects of the drug dominate [68]. Several therapeutic targets have been suggested taking into account the life cycle of JCV and the pathogenesis of PML (Figure 1) [53], but attempts to harness the high points of these targets for treatment intervention have not been clinically very successful in vivo $[68,69]$. The objective of any therapeutic intervention is to disrupt the life cycle of JC virus from the time of infection of the cell through intracellular transformation to the release of newly formed active viral progeny (Figure 1) [53]. These may include inhibition of viral-surface receptor interaction and internalization, DNA replication, transcriptional, and translational processes [53].

Serotonin (5HT2A) receptor antagonist, Mefloquine, a substrate of the P-glycoprotein transporter and antimalarial medication inhibits JC viral adsorption, phagocytosis into the cell, and viral DNA replication. It showed some promise against JCV in vitro [70], but the in vivo result was variable [71]. The same is true of Mefloquine analogue and a serotonin receptor blocker, mirtazapine [72]. The clinical trial with cytarabine (cytosine arabinoside), a Viral DNA synthesis inhibitor, failed to show any clinical benefit in PML patients [73-75] however some studies showed positive results [76-78]. The result of interluekin-2 clinical trial was quite variable and unconvincing $[79,80]$. Similarly, treatment with beta-interferon, an inhibitor of viral replication, yielded variable results [81,82]. The effect of cidofovir, an antiviral drug and inhibitor of viral replication on PML was variable [83,84]. Further, clathrin-mediated endocytosis [38] inhibitor, chlorpromazine, acting singly or in combination with clozapine showed some prospect on glial cell culture in vitro [85] but it was of little or no benefit in clinical trial in vivo [69]. So far, there is no treatment intervention that is effective in addressing the health effects of PML. The objective of any therapeutic intervention in PML is to improve and maintain a very healthy immune system that will promote immune surveillance and prevent immunosuppression. The hypothesis is reinforced by the beneficial effect of IL- 2 administration that restored the immune status and improves the level of CD4+ count [79].

\section{Conclusion}

Several predictions and unanswered questions abound in the pathogenesis of PML with respect to mode of transmission, internal localization of the latent infection, mechanism of reactivation of the rather "quiescent" viral particles, dissemination and establishment of lesions pathognomonic to PML as well as available treatment options that will be beneficial for PML patients. Clearly, any attempts to address these questions would require more research.

\section{Acknowledgements}

DR. R. C. Adiele is a Fellow in the Canadian Institutes of Health Research Training grant in Health Research Using Synchrotron Techniques (CIHR-THRUST). Pharm. C. A. Adiele is a medical writer and we are grateful for her rigorous and insightful review of earlier versions of this article.

\section{Conflict of Interest}

The authors declare that they have no financial or other conflicts of interest in relation to this review article and its publication.

\section{References}

1. Padgett BL, Walker DL, ZuRhein GM, Eckroade RJ, Dessel BH (1971) Cultivation of papova-like virus from human brain with progressive multifocal leucoencephalopathy. Lancet 1: 1257-1260.

2. Gorelik L, Lerner M, Bixler S, Crossman M, Schlain B, et al. (2010) AntiJC virus antibodies: implications for PML risk stratification. Ann Neurol 68: 295-303.

3. Major EO (2010) Progressive multifocal leukoencephalopathy in patients on immunomodulatory therapies. Annu Rev Med 61: 35-47.

4. White MK, Khalili K (2011) Pathogenesis of progressive multifocal leukoencephalopathy--revisited. J Infect Dis 203: 578-586.

5. Reid CE, Li H, Sur G, Carmillo P, Bushnell S, et al. (2011) Sequencing and analysis of JC virus DNA from natalizumab-treated PML patients. J Infect Dis 204: 237-244.

6. Ferenczy MW, Marshall LJ, Nelson CD, Atwood WJ, Nath A, et al. (2012) Molecular biology, epidemiology, and pathogenesis of progressive multifocal leukoencephalopathy, the JC virus-induced demyelinating disease of the human brain. Clin Microbiol Rev 25: 471-506.

7. Frisque RJ, Bream GL, Cannella MT (1984) Human polyomavirus JC virus genome. J Virol 51: 458-469.

8. Baldwin KJ, Hogg JP (2013) Progressive multifocal leukoencephalopathy in patients with multiple sclerosis. Curr Opin Neurol 26: 318-323.

9. Bartt RE (2006) Multiple sclerosis, natalizumab therapy, and progressive multifocal leukoencephalopathy. Curr Opin Neurol 19: 341-349.

10. Kleinschmidt-DeMasters BK, Tyler KL (2005) Progressive multifocal leukoencephalopathy complicating treatment with natalizumab and interferon beta-1a for multiple sclerosis. N Engl J Med 353: 369-374.

11. Langer-Gould A, Atlas SW, Green AJ, Bollen AW, Pelletier D (2005) Progressive multifocal leukoencephalopathy in a patient treated with natalizumab. N Engl J Med 353: 375-381.

12. Schwerdt PR, Schwerdt CE, Silverman L, Rubinstein LJ (1966) Virions associated with progressive multifocal leukoencephalopathy. Virology 29: 511-514.

13. Zurhein G, Chou SM (1965) Particles resembling papova viruses in human cerebral demyelinating disease. Science 148: 1477-1479.

14. Kean JM, Rao S, Wang M, Garcea RL (2009) Seroepidemiology of human polyomaviruses. PLoS Pathog 5: e1000363.

15. Zanotta N, Delbue S, Rossi T, Pelos G, D'Agaro P, et al. (2013) Molecular epidemiology of JCV genotypes in patients and healthy subjects from Northern Italy. J Med Virol 85: 1286-1292.

16. Corti M, Villafañe M, Trione N, Yampolsky C, Sevlever G (2013) Progressive multifocal leukoencephalopathy presenting as IRIS in an AIDS patient. A case report and literature review. Neuroradiol J 26: 151-154. 
17. Falcó V (2013) Progressive multifocal leukoencephalopathy, a rare but devastating disease in AIDS patients. Indian J Med Res 138: 13-15.

18. Martin-Blondel G, Bauer J, Cuvinciuc V, Uro-Coste E, Debard A, et al. (2013) In situ evidence of JC virus control by CD8+ T cells in PML-IRIS during HIV infection. Neurology 81: 964-970.

19. Netravathi M, Mahadevan A, Satishchandra P, Shobha N, Mailankody P, et al. (2013) Progressive multifocal leukoencephalopathy (PML) associated with HIV Clade C--is not uncommon. J Neurovirol 19: 198-208.

20. Santos EM, Silva MT, Lima MA (2013) Progressive multifocal leukoencephalopathy in a HIV/HTLV co-infected patient. J Neurol Sci 325: 174-175.

21. Sharma SK, Soneja M, Ranjan S, Miglani S, Hari S, et al. (2013) Progressive multifocal leucoencephalopathy in HIV/AIDS: observational study from a tertiary care centre in northern India. Indian J Med Res 138: 72-77.

22. D'Souza A, Wilson J, Mukherjee S, Jaiyesimi I (2010) Progressive multifocal leukoencephalopathy in chronic lymphocytic leukemia: a report of three cases and review of the literature. Clin Lymphoma Myeloma Leuk 10: E1-9.

23. Berger JR, Houff S (2006) Progressive multifocal leukoencephalopathy: lessons from AIDS and natalizumab. Neurol Res 28: 299-305.

24. Korman BD, Tyler KL, Korman NJ (2009) Progressive multifocal leukoencephalopathy, efalizumab, and immunosuppression: a cautionary tale for dermatologists. Arch Dermatol 145: 937-942.

25. Bofill-Mas S, Girones R (2003) Role of the environment in the transmission of JC virus. J Neurovirol 9 Suppl 1: 54-58.

26. Bofill-Mas S, Clemente-Casares P, Major EO, Curfman B, Girones R (2003) Analysis of the excreted JC virus strains and their potential oral transmission. J Neurovirol 9: 498-507.

27. Berger JR, Miller CS, Mootoor Y, Avdiushko SA, Kryscio RJ, et al. (2006) JC virus detection in bodily fluids: clues to transmission. Clin Infect Dis 43: e9-12.

28. Monaco MC, Jensen PN, Hou J, Durham LC, Major EO (1998) Detection of JC virus DNA in human tonsil tissue: evidence for site of initial viral infection. J Virol 72: 9918-9923.

29. Caldarelli-Stefano R, Vago L, Omodeo-Zorini E, Mediati M, Losciale L, et al. (1999) Detection and typing of JC virus in autopsy brains and extraneural organs of AIDS patients and non-immunocompromised individuals. J Neurovirol 5: 125-133.

30. Yogo Y, Kitamura T, Sugimoto C, Ueki T, Aso Y, et al. (1990) Isolation of a possible archetypal JC virus DNA sequence from nonimmunocompromised individuals. J Virol 64: 3139-3143.

31. Kato A, Kitamura T, Takasaka T, Tominaga T, Ishikawa A, et al. (2004) Detection of the archetypal regulatory region of JC virus from the tonsil tissue of patients with tonsillitis and tonsilar hypertrophy. J Neurovirol 10: 244-249.

32. Perez-Liz G, Del Valle L, Gentilella A, Croul S, Khalili K (2008) Detection of JC virus DNA fragments but not proteins in normal brain tissue. Ann Neurol 64: 379-387.

33. White FA 3rd, Ishaq M, Stoner GL, Frisque RJ (1992) JC virus DNA is present in many human brain samples from patients without progressive multifocal leukoencephalopathy. J Virol 66: 5726-5734.

34. Elsner C, Dörries K (1992) Evidence of human polyomavirus BK and JC infection in normal brain tissue. Virology 191: 72-80.

35. Azzi A, De Santis R, Ciappi S, Leoncini F, Sterrantino G, et al. (1996) Human polyomaviruses DNA detection in peripheral blood leukocytes from immunocompetent and immunocompromised individuals. J Neurovirol 2: 411-416.

36. Dörries K, Vogel E, Günther S, Czub S (1994) Infection of human polyomaviruses JC and BK in peripheral blood leukocytes from immunocompetent individuals. Virology 198: 59-70.

37. Wroblewska Z, Wellish M, Gilden D (1980) Growth of JC virus in adult human brain cell cultures. Arch Virol 65: 141-148.
38. Pho MT, Ashok A, Atwood WJ (2000) JC virus enters human glial cells by clathrin-dependent receptor-mediated endocytosis. J Virol 74: 2288-2292.

39. Querbes W, Benmerah A, Tosoni D, Di Fiore PP, Atwood WJ (2004) A JC virus-induced signal is required for infection of glial cells by a clathrin- and eps15-dependent pathway. J Virol 78: 250-256.

40. Bergui M, Bradac GB, Oguz KK, Boghi A, Geda C, et al. (2004) Progressive multifocal leukoencephalopathy: diffusion-weighted imaging and pathological correlations. Neuroradiology 46: 22-5.

41. Dugan AS, Gasparovic ML, Atwood WJ (2008) Direct correlation between sialic acid binding and infection of cells by two human polyomaviruses (JC virus and BK virus). J Virol 82: 2560-2564.

42. Liu CK, Wei G, Atwood WJ (1998) Infection of glial cells by the human polyomavirus JC is mediated by an $\mathrm{N}$-linked glycoprotein containing terminal alpha(2-6)-linked sialic acids. J Virol 72: 4643-4649.

43. Elphick GF, Querbes W, Jordan JA, Gee GV, Eash S, et al. (2004) The human polyomavirus, JCV, uses serotonin receptors to infect cells. Science 306: 1380-1383.

44. O'Hara BA, Atwood WJ (2008) Interferon beta1-a and selective anti-5HT(2a) receptor antagonists inhibit infection of human glial cells by JC virus. Virus Res 132: 97-103.

45. Kasamatsu H, Nakanishi A (1998) How do animal DNA viruses get to the nucleus? Annu Rev Microbiol 52: 627-686.

46. Yamada M, Kasamatsu H (1993) Role of nuclear pore complex in simian virus 40 nuclear targeting. J Virol 67: 119-130.

47. Querbes W, O'Hara BA, Williams G, Atwood WJ (2006) Invasion of host cells by JC virus identifies a novel role for caveolae in endosomal sorting of noncaveolar ligands. J Virol 80: 9402-9413.

48. Tada H, Rappaport J, Lashgari M, Amini S, Wong-Staal F, et al. (1990) Trans-activation of the JC virus late promoter by the tat protein of type 1 human immunodeficiency virus in glial cells. Proc Natl Acad Sci U S A 87: 3479-3483.

49. Daniel DC, Kinoshita Y, Khan MA, Del Valle L, Khalili K, et al. (2004) Internalization of exogenous human immunodeficiency virus-1 protein, Tat, by KG-1 oligodendroglioma cells followed by stimulation of DNA replication initiated at the JC virus origin. DNA Cell Bio. 23: 858-67.

50. Wüthrich C, Kesari S, Kim WK, Williams K, Gelman R, et al. (2006) Characterization of lymphocytic infiltrates in progressive multifocal leukoencephalopathy: co-localization of $\mathrm{CD} 8(+) \mathrm{T}$ cells with JCVinfected glial cells. J Neurovirol 12: 116-128.

51. Khalili K, White MK, Lublin F, Ferrante P, Berger JR (2007) Reactivation of JC virus and development of PML in patients with multiple sclerosis. Neurology 68: 985-990.

52. Aksamit AJ Jr (2012) Progressive multifocal leukoencephalopathy. Continuum (Minneap Minn) 18: 1374-1391.

53. Tavazzi E, White MK, Khalili K (2012) Progressive multifocal leukoencephalopathy: clinical and molecular aspects. Rev Med Virol 22: 18-32.

54. Berger JR (2010) Progressive multifocal leukoencephalopathy and newer biological agents. Drug Saf 33: 969-983.

55. Berger JR, Kaszovitz B, Post MJ, Dickinson G (1987) Progressive multifocal leukoencephalopathy associated with human immunodeficiency virus infection. A review of the literature with a report of sixteen cases. Ann Intern Med 107: 78-87.

56. Lima MA, Drislane FW, Koralnik IJ (2006) Seizures and their outcome in progressive multifocal leukoencephalopathy. Neurology 66: 262-264.

57. Giancola ML, Rizzi EB, Lorenzini P, Rovighi L, Baldini F, et al. (2008) Progressive multifocal leukoencephalopathy in HIV-infected patients in the era of HAART: radiological features at diagnosis and follow-up and correlation with clinical variables. AIDS Res Hum Retroviruses 24: $155-62$.

58. Mark AS, Atlas SW (1989) Progressive multifocal leukoencephalopathy in patients with AIDS: appearance on MR images. Radiology 173: 517-520. 
59. Whiteman ML, Post MJ, Berger JR, Tate LG, Bell MD,et al. (1993) Progressive multifocal leukoencephalopathy in 47 HIV-seropositive patients: neuroimaging with clinical and pathologic correlation. Radiology 187: 233-240

60. Post MJ, Yiannoutsos C, Simpson D, Booss J, Clifford DB, et al. (1999) Progressive multifocal leukoencephalopathy in AIDS: are there any MR findings useful to patient management and predictive of patient survival? AIDS Clinical Trials Group, Am J Neuroradiol 20: 1896-906.

61. Du Pasquier RA, Corey S, Margolin DH, Williams K, Pfister LA, et al. (2003) Productive infection of cerebellar granule cell neurons by JC virus in an HIV+ individual. Neurology 61: 775-782.

62. Gheuens S, Wüthrich C, Koralnik IJ (2013) Progressive multifocal leukoencephalopathy: why gray and white matter. Annu Rev Pathol 8 189-215.

63. Koralnik IJ, Wüthrich C, Dang X, Rottnek M, Gurtman A, et al. (2005) JC virus granule cell neuronopathy: A novel clinical syndrome distinct from progressive multifocal leukoencephalopathy. Ann Neurol 57: 576-580.

64. Viallard JF, Ellie E, Lazaro E, Lafon ME, Pellegrin JL (2005) JC virus meningitis in a patient with systemic lupus erythematosus. Lupus 14 : 964-966.

65. Blake K, Pillay D, Knowles W, Brown DW, Griffiths PD, et al. (1992) JC virus associated meningoencephalitis in an immunocompetent girl. Arch Dis Child 67: 956-957.

66. Cinque P, Koralnik IJ, Gerevini S, Miro JM, Price RW (2009) Progressive multifocal leukoencephalopathy in HIV-1 infection. Lancet Infect Dis 9: 625-636.

67. Shah R, Bag AK, Chapman PR, Curé JK (2010) Imaging manifestations of progressive multifocal leukoencephalopathy. Clin Radiol 65: 431-439.

68. De Luca A, Ammassari A, Pezzotti P, Cinque P, Gasnault J, et al. (2008) Cidofovir in addition to antiretroviral treatment is not effective for AIDS-associated progressive multifocal leukoencephalopathy: a multicohort analysis. AIDS 22: 1759-1767.

69. Pöhlmann C, Hochauf K, Röllig C, Schetelig J, Wunderlich O, et al (2007) Chlorpromazine combined with cidofovir for treatment of a patient suffering from progressive multifocal leukoencephalopathy. Intervirology 50: 412-417.

70. Brickelmaier M, Lugovskoy A, Kartikeyan R, Reviriego-Mendoza MM, Allaire N, et al. (2009) Identification and characterization of mefloquine efficacy against JC virus in vitro. Antimicrob Agents Chemother 53: 1840-1849.

71. Schröder A, Lee DH, Hellwig K, Lukas C, Linker RA, et al. (2010) Successful management of natalizumab-associated progressive multifocal leukoencephalopathy and immune reconstitution syndrome in a patient with multiple sclerosis. Arch Neurol 67: 1391-1394.

72. Marzocchetti A, Tompkins T, Clifford DB, Gandhi RT, Kesari S, et al (2009) Determinants of survival in progressive multifocal leukoencephalopathy. Neurology 73: 1551-1558.
73. Hall CD, Dafni U, Simpson D, Clifford D, Wetherill PE, et al. (1998) Failure of cytarabine in progressive multifocal leukoencephalopathy associated with human immunodeficiency virus infection. AIDS Clinical Trials Group 243 Team. N Engl J Med 338: 1345-1351.

74. De Luca A, Giancola ML, Cingolani A, Ammassari A, Gillini L, et al (1999) Clinical and virological monitoring during treatment with intrathecal cytarabine in patients with AIDS- associated progressive multifocal leukoencephalopathy. Clin Infect Dis 28: 624-628.

75. Guarino M, D'Alessandro R, Rinaldi R, Stracciari A, Pazzaglia P, et al. (1995) Progressive multifocal leucoencephalopathy in AIDS: treatment with cytosine arabinoside. AIDS 9: 819-820.

76. Portegies P, Algra PR, Hollak CE, Prins JM, Reiss P, et al. (1991) Response to cytarabine in progressive multifocal leucoencephalopathy in AIDS. Lancet 337: 680-681.

77. Aksamit AJ (2001) Treatment of non-AIDS progressive multifocal leukoencephalopathy with cytosine arabinoside. J Neurovirol 7: 386-390.

78. Nicoli F, Chave B, Peragut JC, Gastaut JL (1992) Efficacy of cytarabine in progressive multifocal leucoencephalopathy in AIDS. Lancet 339: 306.

79. Przepiorka D, Jaeckle KA, Birdwell RR, Fuller GN, Kumar AJ, et al. (1997) Successful treatment of progressive multifocal leukoencephalopathy with low-dose interleukin-2. Bone Marrow Transplant 20: 983-987.

80. Kunschner L, Scott TF (2005) Sustained recovery of progressive multifocal leukoencephalopathy after treatment with IL-2. Neurology 65: 1510.

81. Nath A, Venkataramana A, Reich DS, Cortese I, Major EO (2006) Progression of progressive multifocal leukoencephalopathy despite treatment with beta-interferon. Neurology 66: 149-150.

82. Huang SS, Skolasky RL, Dal Pan GJ, Royal W 3rd, McArthur JC (1998) Survival prolongation in HIV-associated progressive multifocal leukoencephalopathy treated with alpha- interferon: an observational study. J Neurovirol 4: 324-32.

83. De Luca A, Giancola ML, Ammassari A, Grisetti S, Cingolani A, et al. (2000) Cidofovir added to HAART improves virological and clinical outcome in AIDS-associated progressive multifocal leukoencephalopathy. AIDS 14: F117-121.

84. Hou J, Major EO (1998) The efficacy of nucleoside analogs against JC virus multiplication in a persistently infected human fetal brain cell line. J Neurovirol 4: 451-456.

85. Baum S, Ashok A, Gee G, Dimitrova S, Querbes W, et al. (2003) Early events in the life cycle of JC virus as potential therapeutic targets for the treatment of progressive multifocal leukoencephalopathy. J Neurovirol 9 Suppl 1:32-37. 